\title{
30. SUGARS, AMINO ACIDS, AND HYDROCARBONS IN BLACK SEA SEDIMENT FROM DSDP LEG 42B CORES
}

Kenneth Mopper, Walter Michaelis, Corrado Garrasi, and Egon T. Degens, Geologisch-Paläontologisches Institut, University of Hamburg, Hamburg, West Germany

\begin{abstract}
Sugars, amino acids, and lipids have been extracted from a representative profile of Black Sea sediment samples from DSDP Leg 42B Holes 379A, 380A, and Site 381, and from Chain Cruise 120-1, Core 18.

A similar pattern for amino acids exists in all samples. Some trends, however, are evident; glycine, alanine, and serine are the dominant amino acids, and ornithine is the major basic amino acid. The older sediments are depleted in valine and threonine and enriched in serine. An inverse trend with age between the acidics and aromatics is also seen. Apparently, as a result of frequent variations in the depositional environment, the alloisoleucine-isoleucine ratios show no systematic temporal dependence.

The sugar pattern, in contrast, is more variable. These variations appear to be largely attributable to fluctuations in the nature of the organic input: planktonic versus terrigenous. The ratio of glucose to ribose appears to reflect these fluctuations. The older sediments are depleted in gulose, galactose, and the desoxysugars. A good correlation between the sugar-amino acid ratio and percent organic $\mathrm{C}$ exists.

The GC analyses of hydrocarbons show how the relative composition of the alkanes varies with changes in the nature of the organic input and diagenesis. For many of the samples a good correlation exists between the hydrocarbon spectra and the glucoseribose ratio.
\end{abstract}

\section{INTRODUCTION}

Recent Black Sea sediments $(<20,000$ yr $)$ record changes in the depositional environment from oxic, fresh water (low organic carbon), to reducing, marine (high organic carbon). Analyses of the organic constituents mirror these changes (Degens and Mopper, 1975, 1976). Thus, the DSDP Leg $42 \mathrm{~B}$ cores provide an excellent opportunity to examine the long-range fluctuation in depositional environment as well as diagenetic effects. We present in this paper the initial analyses of sugars, amino acids, and hydrocarbons along with possible environmental implications. Background data for the samples analyzed are presented in Table 1.

\section{LIPIDS}

\section{Analytical}

Nine sediment samples from Holes 379, 380/380A, and Site 381 and one sample from Chain core 18 (Cruise 120-1) were examined for their contents of soluble organic compounds. The sediments were washed with acetone and water and then freeze dried. Extraction of the soluble organic fraction was achieved with benzol/methanol (v:2/1) in an ultrasonic bath. The sediment was extracted several times until the extract liquid was colorless. The extracted quantities generally represented $0.1 \%$ of the sediment (dry weight).

Fatty acids were separated from the total extract by column chromatography with $\mathrm{KOH} / \mathrm{SiO}_{2}$. Hydrocarbons were chromatographically separated on a column of neutral kieselgel with petroleum ether as the eluant. For several of the samples, the alkane fraction was removed from the olefins by preparative $\mathrm{AgNO}_{3}$ thin-layer chromatography. The separation of branched and straight chain hydrocarbons was achieved by molecular sieving $(5 \AA)$.

A Varian Model 2740 Gas Chromatograph was employed for all analyses: column $5^{\prime} \times 1 / 8^{\prime \prime}, 1.5 \% \mathrm{OV}$ $101,90^{\circ}-300^{\circ} \mathrm{C}, 2^{\circ} / \mathrm{min}, 30 \mathrm{ml} / \mathrm{min}$ helium. GC peaks were identified by co-injection. Mass spectrographic identifications will be reported elsewhere.

\section{Discussion of Lipid Data}

Our analyses of Black Sea sediments include the following fractions of the soluble organic compounds: $n$-alkanes, isoprenoids, cyclic hydrocarbons, and normal and branched fatty acids. Results of the first GC analyses of the hydrocarbons are depicted in Figures 1 and 2 which show the relative variation in abundances of alkanes in relation to the nature of (i) organic input, and (ii) diagenesis. Isoprenoids, cyclic 
TABLE 1

Background Data

\begin{tabular}{ccccccc}
\hline Sample & $\begin{array}{c}\text { Depth } \\
(\mathrm{m})\end{array}$ & $\% \mathrm{CaCO}_{3}$ & $\%$ Org. C & $\%$ Org. N & C/N & $\begin{array}{c}\text { Assigned Age } \\
\left(\times 10^{6} \mathrm{yr}\right)\end{array}$ \\
\hline Chain 120/18 & 0 & N.D. $^{\mathrm{a}}$ & N.D. $^{\mathrm{a}}$ & N.D. $^{\mathrm{a}}$ & N.D. $^{\mathrm{a}}$ & 0 \\
Chain 120/18 & 0.38 & 13.8 & 8.13 & 1.07 & 7.60 & 0.001 \\
Chain 120/18 & 1.18 & 34.8 & 7.02 & N.D. & N.D. & 0.005 \\
Chain 120/18 & 1.36 & N.D. $^{\mathrm{a}}$ & N.D. $^{\mathrm{a}}$ & N.D. & N.D. & 0.006
\end{tabular}

Hole 379A

$\begin{array}{lrcccrl}6, \mathrm{CC} & 54.5 & 15.3 & 0.79 & 0.22 & 3.59 & 0.06 \\ 11-5 & 99.0 & - & 26.0 & 0.18 & 144.44 & 0.12 \\ 25-3 & 229.8 & 7.8 & 3.71 & 0.29 & 12.79 & 0.20 \\ 29-4 & 269.5 & 1.9 & 7.40 & 0.61 & 12.13 & 0.22 \\ 57-1 & 520.1 & 30.8 & 0.65 & 0.10 & 6.5 & 0.50\end{array}$

Hole 380A

\begin{tabular}{lrrrrrl} 
4-3 dark & 365.0 & 8.3 & 0.39 & 0.24 & 1.63 & 0.90 \\
4-3 light & 365.0 & 26.1 & 0.36 & 0.11 & 3.27 & 1.2 \\
9-5 & 415.7 & 5.8 & 0.35 & 0.25 & 1.40 & 1.3 \\
14-2 & 458.3 & 3.9 & 0.54 & 0.24 & 2.25 & 1.4 \\
20-2 dark & 514.8 & 1.3 & 0.72 & 0.26 & 2.77 & 1.4 \\
20-2 light & 514.8 & 42.8 & 0.48 & 0.21 & 2.29 & 1.4 \\
$25-3$ & 563.7 & 4.8 & 0.67 & 0.18 & 3.72 & 1.7 \\
$35-1$ & 646.0 & 11.5 & N.D. & N.D. & N.D. & 1.9 \\
$37-6$ & 672.8 & - & 1.45 & 0.21 & 6.90 & 2.0 \\
42, CC & 722.0 & 12.3 & 1.80 & 0.21 & 8.57 & 2.3 \\
45 (top) & 742.0 & - & 2.39 & 0.23 & 10.39 & 2.4 \\
$56-3$ & 849.3 & 0.8 & 1.94 & 0.25 & 7.76 & 2.6 \\
62, CC & 912.6 & 7.1 & 0.90 & 0.26 & 3.46 & $\sim 3$ \\
78, CC & 1064.0 & 8.2 & 2.63 & 0.27 & 9.74 & $\sim 4$ \\
& & & & & & \\
Site 381 & & & & & & \\
& & & & & & \\
$23-3$ & 205.0 & 7.5 & 1.20 & 0.33 & 3.64 & 1.8 \\
$29-2$ & 258.2 & 22.9 & 1.14 & 0.18 & 6.33 & 2.2 \\
$29-6$ & 265.3 & 13.3 & 1.56 & 0.17 & 9.18 & 2.3 \\
34 (top) & 304.0 & - & 1.23 & 0.16 & 7.69 & 2.4 \\
$48-4$ & 440.3 & 2.0 & 0.89 & 0.21 & 4.24 & $\sim 3.1$ \\
$54-1$ & 494.0 & - & 1.84 & 0.15 & 12.27 & $\sim 5$ \\
\hline
\end{tabular}

${ }^{\mathrm{a}}$ Not determined.

hydrocarbons, and fatty acids are presently being examined to provide further information.

The hydrocarbon fraction in the region of $\mathrm{C}_{15}-\mathrm{C}_{33}$ of the Recent Black Sea sediment (Chain 120-1/18, Figure 1) shows a strong predominance of alkanes with odd carbon numbers. This suggests that a major fraction of the organic input was of terrigenous origin. A similar hydrocarbon distribution is recognized in Section 381$51-1$. In this case, however, the terrigenous influence is even more apparent; furthermore, diagenetic alteration can be seen. On the other hand, the spectrum for Section 379A-11-5 (Figure 1) shows a typical planktonic hydrocarbon distribution; no preference for alkanes with odd carbon numbers and the intensity maximum is displaced downward to $\mathrm{C}_{18}-\mathrm{C}_{23}$ (Albrecht and Ourisson, 1971). It should be pointed out, however, that the fraction of the extracted alkanes was much smaller than expected for a sediment containing $26 \%$ organic carbon and is perhaps not characteristic of the sample as a whole.

Sections 379A-57-1, 380A-37-6, and 380A-62, CC yielded spectra which indicate mixed inputs; that is, dominant planktonic with varying degrees of ter- rigenous contributions. An interesting trend is seen in Sections 381-29-2, 381-29-6, and 381-34 (top). The samples are of planktonic origin, but with an increasing terrigenous influence with depth. This trend is also observed with the sugars (Table 3 , glucose/ribose).

\section{AMINO ACIDS}

\section{Analytical}

In general, 50-100 mg dried, crushed sediment were hydrolyzed according to the methods of Degens and Reuter (1964), with one modification. To hinder secondary condensation during rotary evaporation 20 $\mu$ l glycerin were added (Mopper and Dawson, personal communication). The amino acids were chromatographically separated and measured with a Biotronik Model 6000 automatic ion-exchange analyzer coupled to an integrator.

\section{Discussion of Amino Acid Data}

Table 2 lists data from DSDP Leg 42B, Holes 379A, 380A, Site 381, and Chain Cruise 120, Core 18, 


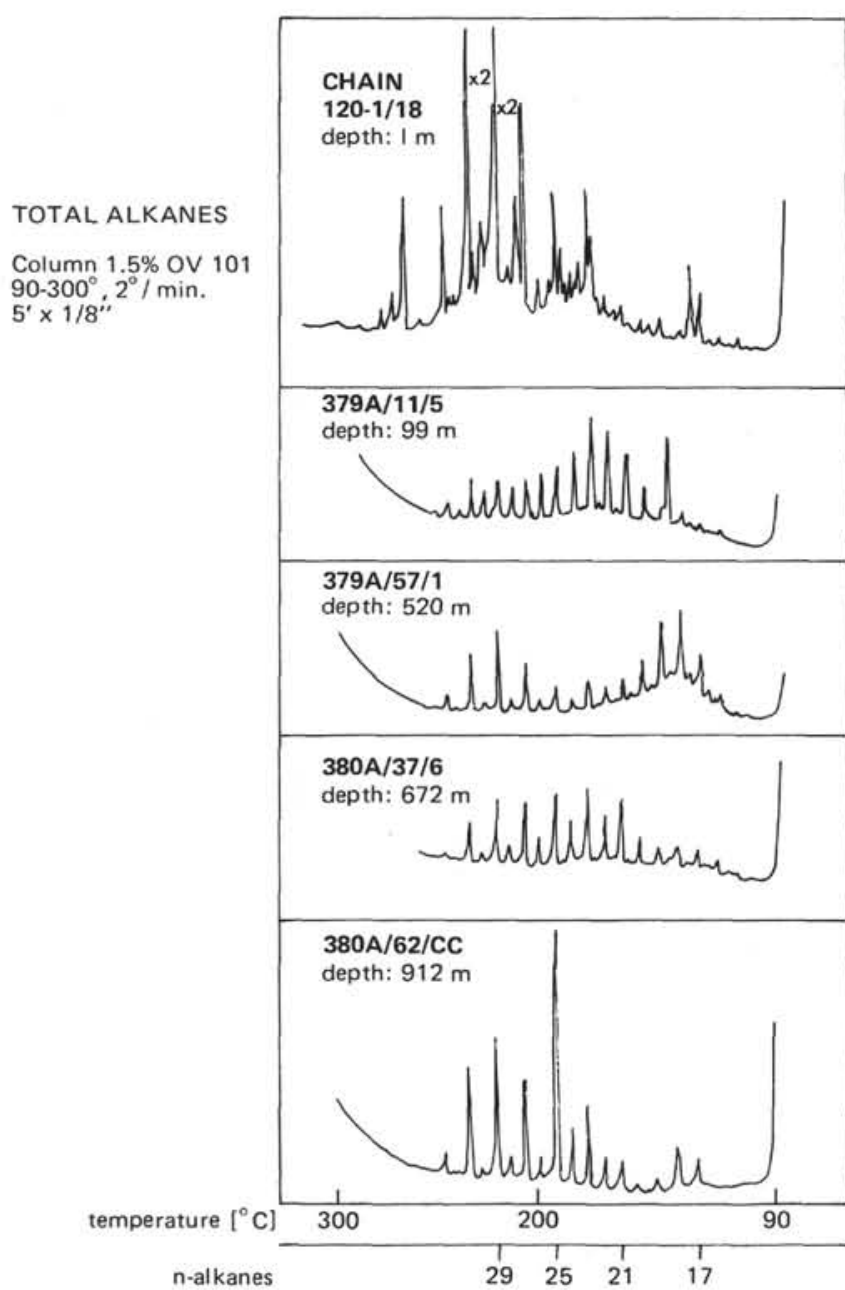

Figure 1. Gas chromatograms of total alkanes (Black Sea sediment). Conditions: stainless steel column $\left(5^{\prime} \times\right.$ $\left.1 / 8^{\prime \prime}\right)$; $1.5 \%$ OV 101 ; temperature programmed from $90^{\circ}-300^{\circ} \mathrm{C}$ at $2^{\circ} / \mathrm{min}$.

according to depth and age. The age assignment is based on work by Stoffers et al. (this volume).

Despite large variations in sediment type and organic carbon contents, the distribution of amino acids is rather uniform. The average concentration of total amino acids is low, ranging from less than $0.3 \mathrm{mg} / \mathrm{g}$ in the older sediments to about $7 \mathrm{mg} / \mathrm{g}$ in the modern sediments.

Within the individual amino acid groups, all of the major protein building amino acids are present. Examination of the data for the modern sediments (Chain 120-1, Table 2) reveals the following order of abundance: neutral $>$ basic $>$ aromatic $>$ acidic $>$ scontaining. Within the neutral fraction the order is valine $>$ threonine $>$ glycine $>$ alanine. Ornithine is the dominant basic amino acid. The absence of $\beta$-alanine suggests that diagenetic effects are minimal.

In the three sediment samples from Hole 379A, the order of abundance within the amino acid groups is variable. The neutrals, however, are still dominant and the sapropel sample (379A-11-5, $99 \mathrm{~m})$ shows an identical order of abundance for the amino acid groups

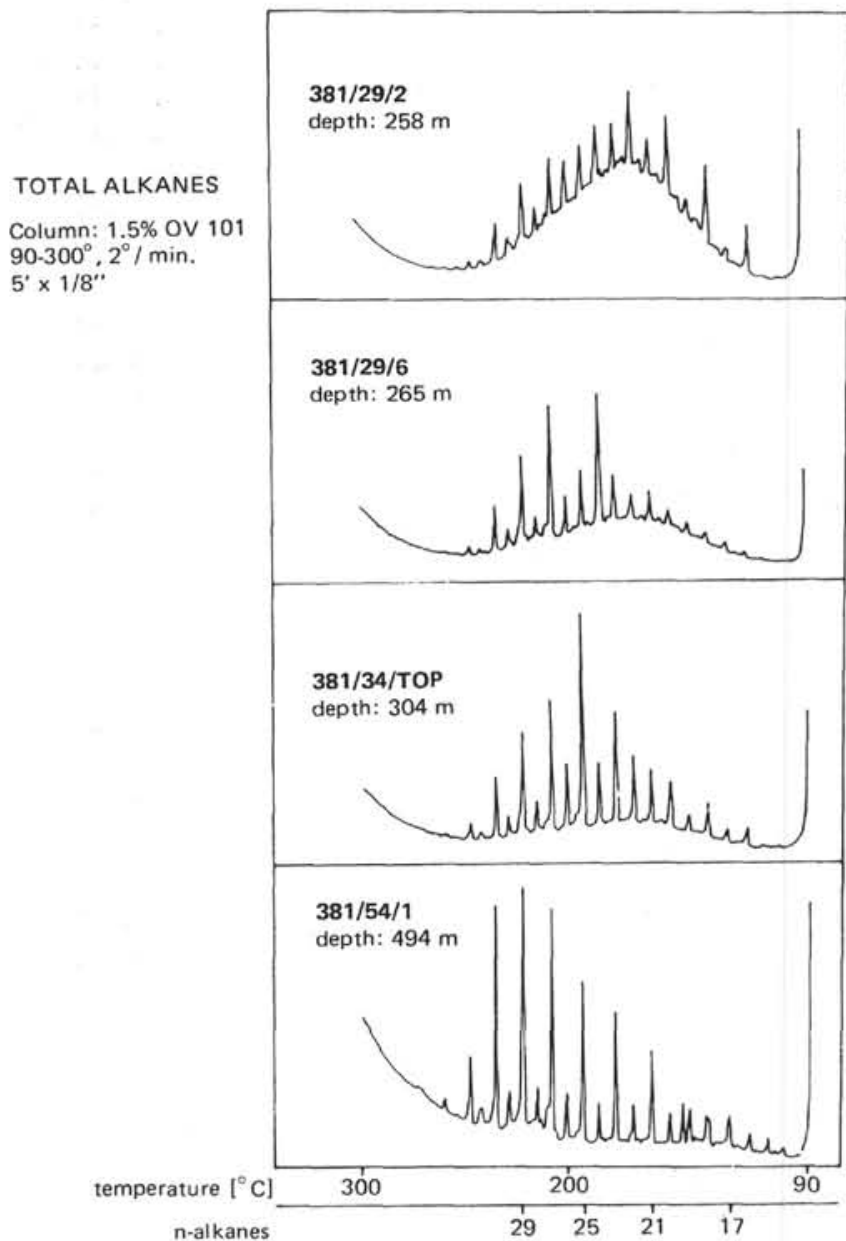

Figure 2. Gas chromatograms of total alkanes (Black Sea sediment). Conditions: stainless steel column $\left(5^{\prime} \times\right.$ $\left.1 / 8^{\prime \prime}\right)$; $1.5 \%$ OV 101 ; temperature programmed from $90^{\circ}-300^{\circ} \mathrm{C}$ at $2^{\circ} / \mathrm{min}$.

as the modern sapropel (Chain 120-1). Possible interpretations are discussed in the section "General Trends." Noteworthy is the unusually high concentration of tyrosine in Section 379A-57-1.

Characteristic of nearly all samples from Hole $380 \mathrm{~A}$ is the order of abundance: glycine $>$ serine $>$ alanine. The exception is Section 380A-35-1. The order of abundance for Site 381 is: serine $>$ glycine $>$ alanine. For both cores ornithine is the major basic amino acid. When compared to modern sediments, the older sediments are depleted in valine and threonine and enriched in serine; $\beta$-alanine is present in all the older strata. Furthermore, a general inverse trend with depth is seen between the acidics and aromatics. A similar trend was noted by Nissenbaum et al. (1972) in Dead Sea sediments.

As with the sugars, the change in depositional environment from reducing to oxidizing in Section 380A-20-2 (dark and light) is reflected in the data. For example the percent amino acid carbon of the total organic carbon decreases in the direction of reducing to oxidizing. This was also noted by Nissenbaum et al. (1972). Further, the relative percentage of acidics 
TABLE 2

Distribution of Amino Acids and Amino Sugars in Black Sea Sediments After Acidic Hydrolysis

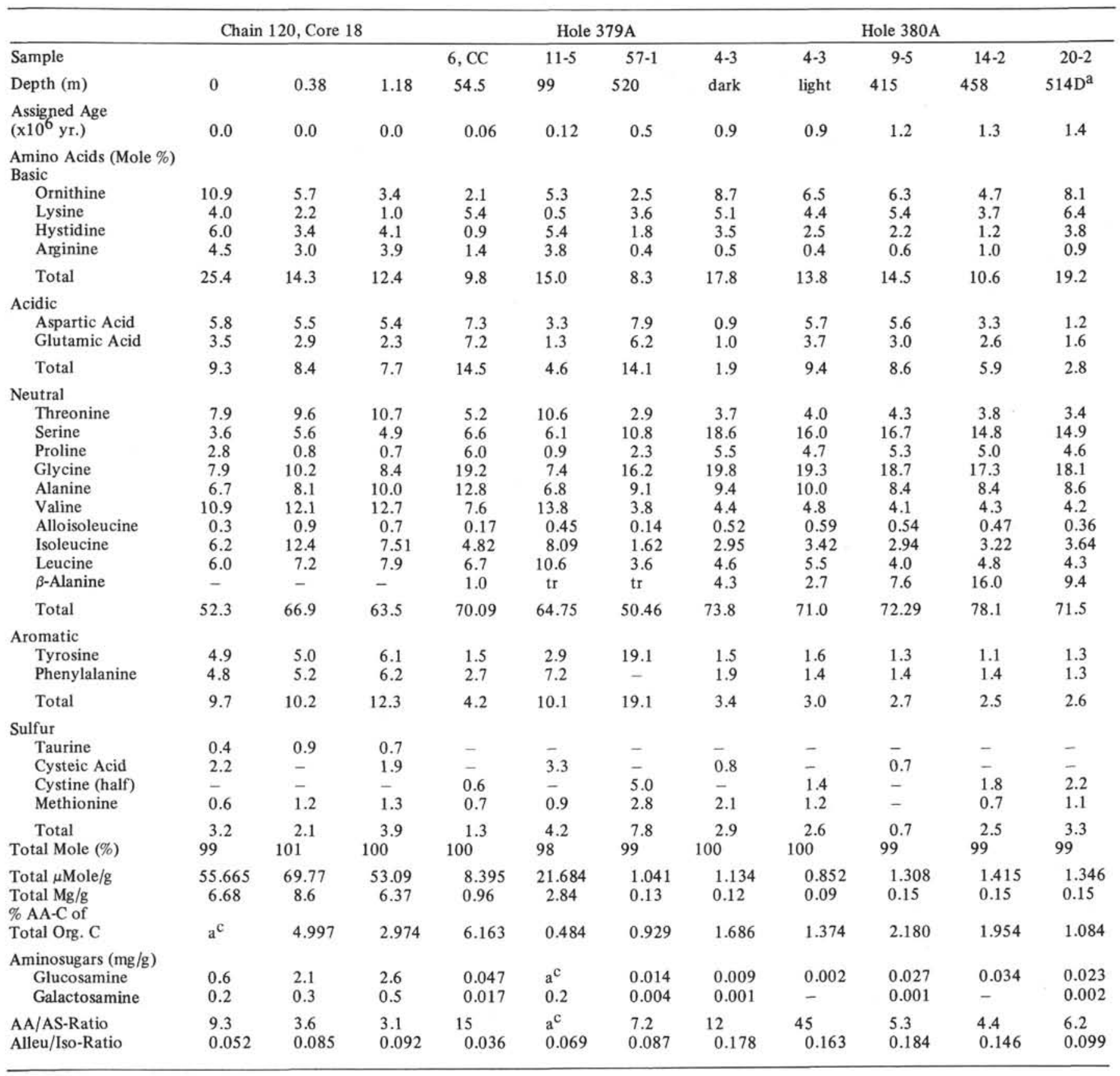

${ }^{\mathrm{a}} \mathrm{D}=\mathrm{Dark}$

$\mathrm{b}_{\mathrm{L}}=$ Light

$\mathrm{c}=$ Not calculated.

increases in the direction reducing to oxidizing. Degens and Mopper (1976) showed that acidic amino acids readily enter into stable metal ion associations. These associations appear to be either preferentially stable to biological degradation or the product of intense biological degradation and thus tend to accumulate in oxic sediment. Similar trends are also observed for Section 380A-4-3.

The alloisoleucine-isoleucine ratios for the sediment samples are listed at the bottom of Table 2. For Hole
$379 \mathrm{~A}$ an increasing trend in the alloisoleucineisoleucine ratio is recognizable with age $(0-500,000$ years). The section is principally composed of terrigenous material. In contrast, the ratios fluctuate in a non-systematic fashion in the older rock strata (500,000-5 million years) These strata are dominantly chemical facies (Stoffers et al., this volume). Thus it appears that the frequent changes in the depositional environment in the Black Sea apparently had a greater effect on this ratio than diagenetic interconversion. 
TABLE 2 - Continued

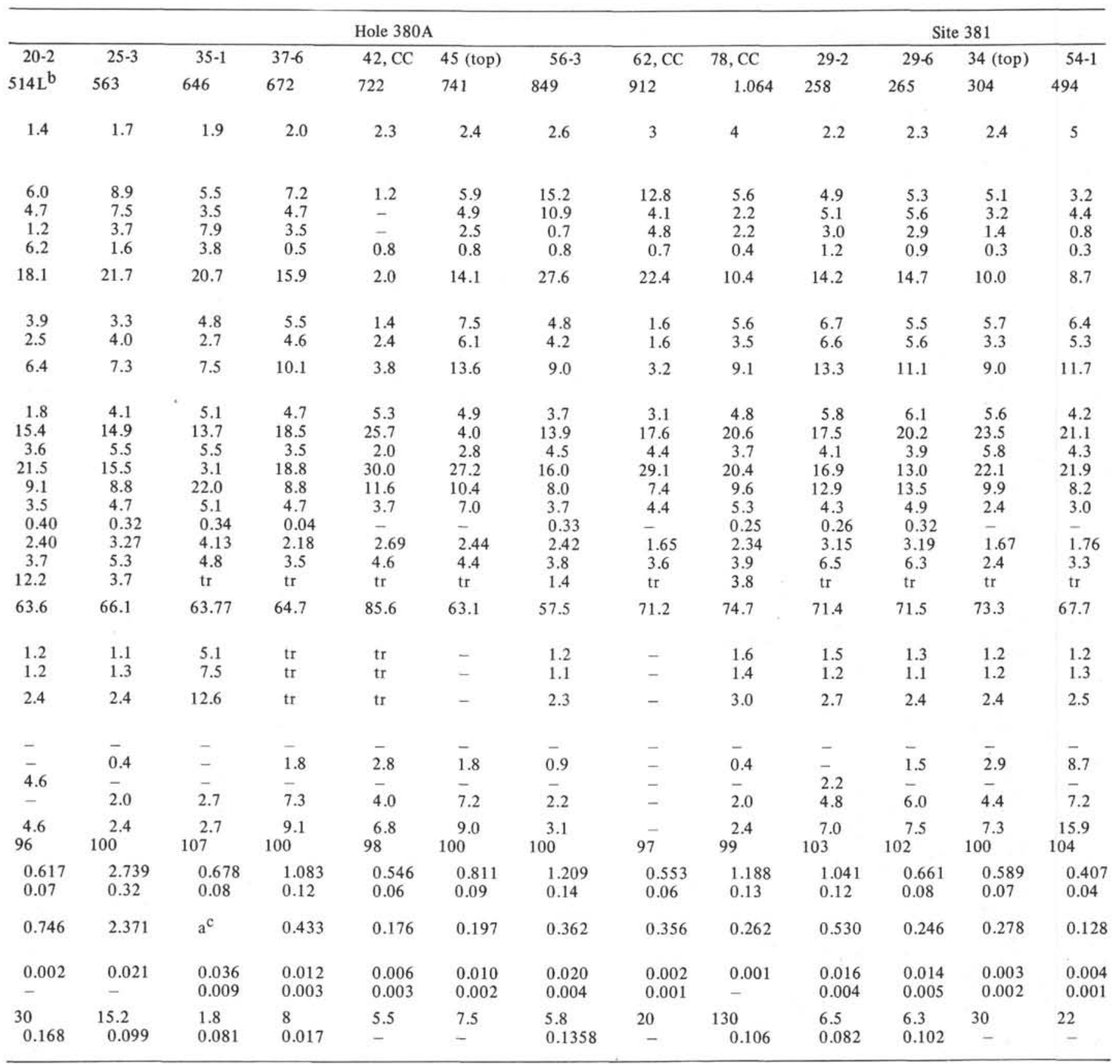

\section{SUGARS}

\section{Analytical}

Generally 200-600 mg of dried, crushed sediment were extracted. The hydrolysis conditions needed to achieve optimal yield and reproducibility have been carefully examined and the results are presented in full elsewhere (Mopper, 1973; in press). A summary of these results for Sections $380 \mathrm{~A}-37-6$ and $381-23-3$ is given in Table 3. It can be seen that $2.0 \mathrm{~N} \mathrm{HCl}, 3$ hours, $100^{\circ} \mathrm{C}$ and $72 \% \mathrm{H}_{2} \mathrm{SO}_{4}$ treatment followed by dilution and hydrolysis for 4 hours, $100^{\circ} \mathrm{C}$, gave the highest yields and nearly identical sugar distributions. The order of hydrolysis efficiency is $72 \% \mathrm{H}_{2} \mathrm{SO}_{4} \cong 2.0 \mathrm{~N}$
$\mathrm{HCl}>72 \%$ p-toluene sulfonic acid (ptsa) $>1.0 \mathrm{~N}$ ptsa $>2.0 \mathrm{~N} \mathrm{H}_{2} \mathrm{SO}_{4}$. The $2.0 \mathrm{~N} \mathrm{HCl}$ method was initially selected over the $72 \% \mathrm{H}_{2} \mathrm{SO}_{4}$ method because of its simplicity and its somewhat better yields of pentoses and desoxysugars (Table 3 ). However, midway through the analyses it was discovered that the $72 \% \mathrm{H}_{2} \mathrm{SO}_{4}$ method is indeed superior. This is readily seen in Table 3. Section 381-23-3. Apparently samples containing a large percentage of hexose-containing polysaccharides are poorly hydrolyzed by $2.0 \mathrm{~N} \mathrm{HCl}$. The higher yields after $72 \% \mathrm{H}_{2} \mathrm{SO}_{4}$ treatment are attributable to swelling of polysaccharides and partial cleavage of glycosidic bonds in the strong acid. In order to minimize the destruction of labile sugars, such as desoxysugars and 
TABLE 3

Sugars in Two Black Sea Sediment Samples Released Under Different Hydrolysis Conditions

\begin{tabular}{|c|c|c|c|c|c|c|c|c|c|c|}
\hline & \multicolumn{10}{|c|}{$380 \mathrm{~A}-37-6$} \\
\hline & \multicolumn{5}{|c|}{$\mu \mathrm{mole} / \mathrm{g}$} & \multicolumn{5}{|c|}{ mole \% } \\
\hline & $\begin{array}{l}2.0 \mathrm{~N} \mathrm{HCl} \\
3 \mathrm{hr}, 100^{\circ} \mathrm{C}\end{array}$ & $\begin{array}{c}2.0 \mathrm{~N} \\
\mathrm{H}_{2} \mathrm{SO}_{4} \\
4 \mathrm{hr}, 100^{\circ} \mathrm{C}\end{array}$ & $\begin{array}{l}72 \% \mathrm{H}_{2} \mathrm{SO}_{4}{ }^{\mathrm{a}} \\
\rightarrow 1.86 \mathrm{~N}^{\circ} \\
4 \mathrm{hr}, 100^{\circ} \mathrm{C}\end{array}$ & $\begin{array}{c}1.0 \mathrm{~N} \text { ptsa } \\
4 \mathrm{hr}, 100^{\circ} \mathrm{C}\end{array}$ & $\begin{array}{c}72 \% \text { ptsa } \\
\rightarrow 0.93 \mathrm{~N} \\
4 \mathrm{hr}, 100^{\circ} \mathrm{C}\end{array}$ & $\begin{array}{c}2.0 \mathrm{~N} \mathrm{HCl} \\
3 \mathrm{hr}, 100^{\circ} \mathrm{C}\end{array}$ & $\begin{array}{c}2.0 \mathrm{~N} \\
\mathrm{H}_{2} \mathrm{SO}_{4} \\
4 \mathrm{hr}, 100^{\circ} \mathrm{C}\end{array}$ & $\begin{array}{c}72 \% \mathrm{H}_{2} \mathrm{SO}_{4}{ }^{\mathrm{a}} \\
1.86 \mathrm{~N} \\
4 \mathrm{hr}, 100^{\circ} \mathrm{C}\end{array}$ & $\begin{array}{l}1.0 \mathrm{~N} \mathrm{ptsa} \\
4 \mathrm{hr}, 100^{\circ} \mathrm{C}\end{array}$ & $\begin{array}{c}72 \% \text { ptsa } \\
0.93 \mathrm{~N} \\
4 \mathrm{hr}, 100^{\circ} \mathrm{C}\end{array}$ \\
\hline \multicolumn{11}{|l|}{ Sugars } \\
\hline Rhamnose & 0.061 & 0.011 & 0.054 & 0.010 & 0.015 & 9.4 & 7.4 & 7.7 & 3.8 & 4.7 \\
\hline Fucose & 0.047 & 0.008 & 0.041 & 0.005 & 0.008 & 7.3 & 5.6 & 5.9 & 2.0 & 2.5 \\
\hline Ribose & 0.048 & 0.005 & 0.042 & 0.005 & 0.005 & 7.4 & 3.4 & 6.1 & 1.9 & 1.6 \\
\hline Lyxose & 0.048 & tr & 0.044 & 0.006 & 0.005 & 7.4 & $\mathrm{tr}$ & 6.3 & 2.3 & 1.8 \\
\hline Arabinose & 0.068 & 0.016 & 0.138 & 0.063 & 0.044 & 10.5 & 11.2 & 19.7 & 23.4 & 14.4 \\
\hline Xylose & 0.058 & 0.014 & 0.062 & 0.029 & 0.045 & 8.9 & 9.3 & 8.8 & 10.8 & 14.7 \\
\hline Fructose & 0.045 & 0.005 & 0.043 & 0.007 & 0.018 & 6.9 & 3.2 & 6.1 & 2.7 & 5.9 \\
\hline Sorbose & 0.044 & - & 0.040 & 0.002 & tr & 6.8 & - & 5.8 & 0.8 & $\mathrm{tr}$ \\
\hline Mannose & 0.071 & 0.026 & 0.077 & 0.050 & 0.049 & 11.0 & 17.7 & 11.1 & 18.7 & 15.9 \\
\hline Gulose & - & - & - & - & - & - & 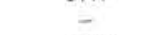 & - & - & - \\
\hline Galactose & 0.053 & 0.022 & 0.059 & 0.013 & 0.021 & 8.1 & 14.8 & 8.6 & 5.0 & 6.8 \\
\hline Glucose & 0.106 & 0.040 & 0.099 & 0.077 & 0.097 & 16.3 & 27.4 & 14.1 & 28.7 & 31.6 \\
\hline Total & 0.648 & 0.146 & 0.699 & 0.268 & 0.307 & 100 & 100 & 100 & 100 & 100 \\
\hline $\begin{array}{l}\text { \% Sugar-C } \\
\text { of Total }\end{array}$ & & & & & & & & & & \\
\hline Organic-C & 0.30 & 0.07 & 0.32 & 0.12 & 0.14 & & & & & \\
\hline $\begin{array}{l}\text { Glucose/ } \\
\text { Ribose }\end{array}$ & 2.2 & 8.0 & 2.4 & 15.4 & 19.4 & & & & & \\
\hline
\end{tabular}

pentoses, during the $72 \% \mathrm{H}_{2} \mathrm{SO}_{4}$ treatment, the samples were kept at $0^{\circ} \mathrm{C}$ for several minutes during and after the addition of the acid. In Table 4 some samples were analyzed by the $2.0 \mathrm{~N} \mathrm{HCl}$ method, where others were by the $72 \% \mathrm{H}_{2} \mathrm{SO}_{4}$ method. This should be kept in mind when examining the data. For example, the low abundances of hexoses in Sections 380A-35-1, 380A-42, CC, 380A-45 (top), 381-29-2, and 381-54-1, may reflect incomplete extraction as opposed to the true distribution. All samples are being re-extracted using the $72 \%$ $\mathrm{H}_{2} \mathrm{SO}_{4}$ method and the results will be presented at a future time.

After hydrolysis the samples are deionized and "cleaned" with ion-exchange resins and reduced to an exact volume (Mopper, in press). The sugars are then separated and measured by automatic liquid chromatography. Separations are achieved through partition chromatography on a column of fine-grained anion exchange resin, Durrum DAX8 $(11 \mu \mathrm{m})$ in the sulfate form. The eluant is $87 \mathrm{w} / \mathrm{w} \%$ ethanol and the locating agent is a non-corrosive copper (I) complex of bicinchoninate. The eluate is monitored by a spectrophotometer. The reproducibility of the present system is better than $5 \%$ at the $10^{-9}$ mole level. Details of the system are given elsewhere (Mopper and Degens, 1972; Mopper and Gindler, 1973). A typical chromatogram is shown in Figure 3.

\section{Discussion of Sugar Data}

The use of two hydrolysis methods may prove to give valuable insights into the sources of organic inputs into sediment. The $2 \mathrm{~N} \mathrm{HCl}$ method appears to release sugars dominantly from algal polysaccharides. Resistant polysaccharides, such as cellulose, which are derived mainly from terrigenous plants, require the $72 \%$ $\mathrm{H}_{2} \mathrm{SO}_{4}$ treatment. Thus the difference between the two extracts represents the approximate terrigenous organic input. Two samples have been analyzed by these methods and the results are given in Table 3 . The hydrocarbon profile for Section 380A-37-6 (Fig. 1) provides evidence for a dominant marine input (e.g., plankton). The sugar data for this sample (Table 3 ) show only minor differences between the $2.0 \mathrm{~N} \mathrm{HCl}$ and $72 \% \mathrm{H}_{2} \mathrm{SO}_{4}$ extracts. Thus, probably less than $10 \%$ of the organic input was terrigenous. On the other hand, Section 381-23-3 (Table 3) shows a threefold difference between the two extracts, suggesting that as much as two-thirds of the input was terrigenous. Similar information may be obtained by examing only the $72 \%$ $\mathrm{H}_{2} \mathrm{SO}_{4}$ extract. Changes in the glucose-ribose ratio within this extract apparently reflect relative changes in terrigenous versus planktonic input. A high ratio $(>25)$ indicates terrigenous sources while a low ratio $(<15)$, planktonic sources (Mopper, 1973; Degens and Mopper, 1975).

Examining the glucose-ribose ratio for the various samples in Table 4 and Figure 4 reveals that the organic input fluctuates between planktonic and terrigenous. This trend is especially clear in Chain Core 18 where a sharp break between the younger sapropellic marine sediments and the older fresh-water sediment $(1.36 \mathrm{~m})$ is seen. Microscopic examination of the latter reveals a large fraction of land-derived reworked Cretaceous and Tertiary marine limestones, thus providing independent evidence of the validity of the glucose-ribose relationship. Additional verification comes from hydrocarbon analyses. In general good correlations exist between the hydrocarbon spectra and the glucose-ribose ratio. The two discrepancies (379-11-5 and 381-54-1) are discussed in the section "General Trends."

Section 380-20-2 (dark and light) represents a transition from a reducing (dark) to an oxidizing environment. Despite this radical chemical change, the glucose-ribose ratios are nearly identical, suggesting 
TABLE 3 - Continued

\begin{tabular}{|c|c|c|c|}
\hline \multicolumn{4}{|c|}{$381-23-3$} \\
\hline \multicolumn{2}{|r|}{$\mu$ mole/g } & \multicolumn{2}{|c|}{ mole $\%$} \\
\hline $\begin{array}{l}2.0 \mathrm{~N} \mathrm{HCl} \\
3 \mathrm{hr}, 100^{\circ} \mathrm{C}\end{array}$ & $\begin{array}{c}72 \% \mathrm{H}_{2} \mathrm{SO}_{4}^{\mathrm{a}} \\
1.86 \mathrm{~N} \\
4 \mathrm{hr}, 100^{\circ} \mathrm{C}\end{array}$ & $\begin{array}{c}2.0 \mathrm{~N} \mathrm{HCl} \\
3 \mathrm{hr}, 100^{\circ} \mathrm{C}\end{array}$ & $\begin{array}{c}72 \% \mathrm{H}_{2} \mathrm{SO}_{4}{ }^{\mathrm{a}} \\
1.86 \mathrm{~N} \\
4 \mathrm{hr}, 100^{\circ} \mathrm{C}\end{array}$ \\
\hline 0.054 & 0.071 & 20.5 & 9.1 \\
\hline 0.021 & 0.006 & 8.0 & 0.8 \\
\hline 0.004 & 0.003 & 1.5 & 0.4 \\
\hline $\mathrm{tr}$ & 0.007 & - & 0.9 \\
\hline 0.070 & 0.047 & 26.6 & 6.0 \\
\hline 0.021 & 0.091 & 8.0 & 11.7 \\
\hline- & 0.008 & - & 1.0 \\
\hline- & - & - & - \\
\hline 0.009 & 0.189 & 3.4 & 24.2 \\
\hline - & - & - & - \\
\hline 0.035 & 0.072 & 13.3 & 9.2 \\
\hline 0.049 & 0.286 & 18.6 & 36.6 \\
\hline 0.263 & 0.781 & 100 & 100 \\
\hline 0.15 & 0.45 & & \\
\hline 12.3 & 95.3 & & \\
\hline
\end{tabular}

that the nature of the organic input remained constant. However, there are differences between the samples. For example, the percent of the total organic carbon represented by sugar is reduced by a factor of 2.6 in the oxic sediment. Furthermore, hexoses are more abundant in this sample. Both facts support the hypothesis that biological consumption in the oxic sediment is more intense than in the reducing sediment. Thus, the easily consumed sugars were eliminated leaving an enrichment in hexoses (probably in the form of cellulose and related polysaccharides).

Other trends exist in the data (Table 4), for example gulose, galactose, and the desoxysugars are more abundant in the younger sediments. Further, arabinose and occasionally fructose are present in unusually high concentrations in some of the older sediments. These sugars may be selectively preserved through diagenetic incorporation into metal ion-organic associations (Mopper, 1973).

\section{GENERAL TRENDS}

Figure 4 shows temporal variations in several parameters. Good correlations among the $\mathrm{C} / \mathrm{N}$ and sugar/AA ratios and \% organic carbon can be seen. Sugars appear to be enriched in those sediments high in organic carbon; this is especially true of the younger sediments where the abundance of total sugars is equal to or greater than that of amino acids. In the younger sediments the proportion of sugars to amino acids appears to be a function of the input composition. The source of the amino acids is probably plankton (indigenous) where that of the sugars is partially plankton and partially land plant debris (allochthonous).Thus, the large terrigenous input in the upper sediments $\left(0.0-0.1 \times 10^{6}\right.$ years $)$ yielded high sugar/AA ratios. Between 0.4-1.4 $\times 10^{\circ}$ years marine sources probably dominated and, hence, the lower sugar/AA

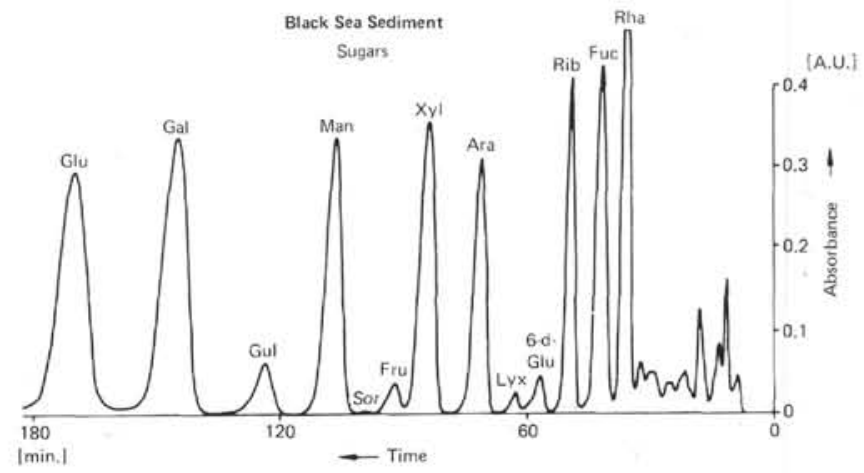

Figure 3. Black Sea sediment-sugars. Chain 120-1, Core 18, 1.18 meters.
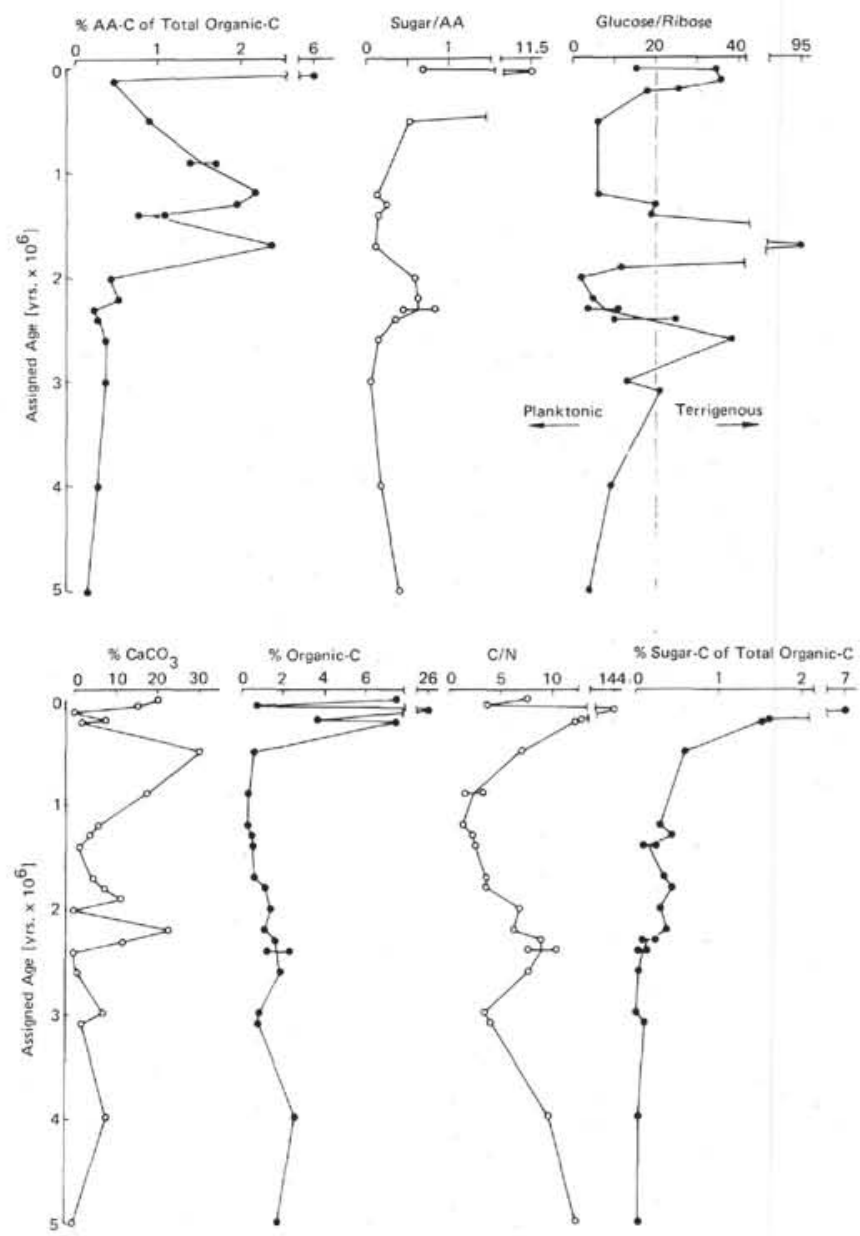

Figure 4. Black Sea sediment-temporal variations: \%AA-C of total organic-C, sugars/AA, glucose/Ribose, \% CaCO3, $\%$ organic $C, C / N, \%$ sugar-C of total organic-C.

ratios. Below $1.4 \times 10^{6}$ years this ratio shows no apparent correlation to the probable source of organic input (glucose-ribose ratio), and thus may be diagenetically controlled.

Below $2 \times 10^{6}$ years the percent sugar and AA carbon of the total organic carbon (Tables 2 and 4, Figure 4) falls off sharply. At present we are not certain whether this decline is due to diagenesis or to high biological activity (consumption) at the sediment-water interface 
TABLE 4

Sugars in Black Sea Sediment After Acid Hydrolysis, Mole \%

\begin{tabular}{|c|c|c|c|c|c|c|c|c|c|c|c|c|c|}
\hline \multirow[b]{2}{*}{ Sample } & \multicolumn{4}{|c|}{ Chain 120 , Core 18} & \multicolumn{4}{|c|}{ Hole $379 \mathrm{~A}$} & \multicolumn{5}{|c|}{ Hole $380 \mathrm{~A}$} \\
\hline & & & & & $11-5$ & $25-3$ & $29-4$ & $57-1$ & $9-5$ & $14-2$ & $20-2$ & $20-2$ & $25-3$ \\
\hline Depth (m) & $0^{\mathrm{a}}$ & $0.38^{\mathrm{a}}$ & $1.18^{\mathrm{a}}$ & $1.36^{\mathrm{a}}$ & 99 & 230 & 270 & $520^{\mathrm{a}}$ & 415 & 458 & $\begin{array}{l}\text { dark } \\
514\end{array}$ & $\begin{array}{l}\text { light } \\
514\end{array}$ & 563 \\
\hline $\begin{array}{l}\text { Assigned Age } \\
\left(\times 10^{6} \mathrm{yr}\right)\end{array}$ & 0.0 & 0.0 & 0.0 & 0.0 & 0.12 & 0.20 & 0.22 & 0.50 & 1.2 & 1.3 & 1.4 & 1.4 & 1.7 \\
\hline \multicolumn{14}{|l|}{ Sugars } \\
\hline \multicolumn{14}{|l|}{ Desoxy } \\
\hline $\begin{array}{l}\text { Rhamnose } \\
\text { Fucose }\end{array}$ & $\begin{array}{r}11.9 \\
9.0\end{array}$ & $\begin{array}{r}12.1 \\
7.6\end{array}$ & $\begin{array}{r}16.1 \\
8.6\end{array}$ & $\begin{array}{l}8.1 \\
8.6\end{array}$ & $\begin{array}{l}7.2 \\
2.1\end{array}$ & $\begin{array}{r}11.4 \\
8.3\end{array}$ & $\begin{array}{r}17.9 \\
3.7\end{array}$ & $\begin{array}{r}11.6 \\
4.3\end{array}$ & $\begin{array}{r}10.6 \\
3.3\end{array}$ & $\begin{array}{l}9.5 \\
1.1\end{array}$ & $\begin{array}{l}6.9 \\
1.1\end{array}$ & $\begin{array}{l}4.3 \\
2.9\end{array}$ & $\begin{array}{r}11.7 \\
0.9\end{array}$ \\
\hline Total & 20.9 & 19.7 & 24.7 & 16.7 & 9.3 & 19.7 & 21.6 & 15.9 & 13.9 & 10.6 & 8.0 & 7.2 & 12.6 \\
\hline \multicolumn{14}{|l|}{ Pentoses } \\
\hline $\begin{array}{l}\text { Ribose } \\
\text { Lyxose } \\
\text { Arabinose } \\
\text { Xylose }\end{array}$ & $\begin{array}{l}1.3 \\
0.3 \\
7.7 \\
7.0^{\mathrm{c}}\end{array}$ & $\begin{array}{l}1.4 \\
0.2 \\
5.0 \\
9.1^{\mathrm{c}}\end{array}$ & $\begin{array}{l}1.6 \\
0.3 \\
2.7 \\
6.1^{\mathrm{c}}\end{array}$ & $\begin{array}{l}0.4 \\
\text { tr } \\
9.7 \\
1.3\end{array}$ & $\begin{array}{r}1.0 \\
0.2 \\
13.7 \\
10.9\end{array}$ & $\begin{array}{r}0.9 \\
0.6 \\
5.3 \\
11.1\end{array}$ & $\begin{array}{r}1.7 \\
0.2 \\
2.5 \\
13.6\end{array}$ & $\begin{array}{r}2.9 \\
1.1 \\
13.1 \\
8.0\end{array}$ & $\begin{array}{r}4.0 \\
6.6 \\
7.9 \\
11.3\end{array}$ & $\begin{array}{r}1.7 \\
1.1 \\
14.9 \\
5.5\end{array}$ & $\begin{array}{r}2.2 \\
2.2 \\
10.2 \\
9.5\end{array}$ & $\begin{array}{l}2.9 \\
\overline{4.3} \\
8.7\end{array}$ & $\begin{array}{r}2.0 \\
2.3 \\
6.3 \\
11.5\end{array}$ \\
\hline Total & 16.3 & 15.7 & 10.7 & 11.5 & 25.8 & 17.9 & 18.0 & 25.1 & 29.8 & 23.2 & 24.1 & 15.9 & 22.1 \\
\hline \multicolumn{14}{|l|}{ Ketohexoses } \\
\hline $\begin{array}{l}\text { Fructose } \\
\text { Sorbose }\end{array}$ & - & $\begin{array}{l}- \\
-\end{array}$ & - & $\begin{array}{l}8.7 \\
-\end{array}$ & $\begin{array}{l}0.2 \\
0.1\end{array}$ & $\begin{array}{l}4.6 \\
-\end{array}$ & $\begin{array}{l}0.7 \\
-\end{array}$ & $\begin{array}{l}8.4 \\
-\end{array}$ & 7.3 & 1.1 & $\begin{array}{l}3.6 \\
1.1\end{array}$ & 5.8 & $\begin{array}{c}4.3 \\
\mathrm{tr}\end{array}$ \\
\hline Total & - & - & - & 8.7 & 0.3 & 4.6 & 0.7 & 8.4 & 7.3 & 1.1 & 4.7 & 5.8 & 4.3 \\
\hline \multicolumn{14}{|l|}{ Aldohexoses } \\
\hline $\begin{array}{l}\text { Mannose } \\
\text { Gulose } \\
\text { Galactose } \\
\text { Glucose }\end{array}$ & $\begin{array}{r}21.4 \\
2.8 \\
20.4 \\
18.2\end{array}$ & $\begin{array}{r}16.1 \\
3.3 \\
23.3 \\
21.9\end{array}$ & $\begin{array}{r}17.9 \\
0.8 \\
19.4 \\
26.5\end{array}$ & $\begin{array}{r}13.8 \\
0.3 \\
21.7 \\
27.2\end{array}$ & $\begin{array}{c}5.0 \\
\text { tr } \\
23.9 \\
35.6\end{array}$ & $\begin{array}{r}15.5 \\
2.8 \\
19.8 \\
23.8\end{array}$ & $\begin{array}{r}15.9 \\
2.1 \\
10.4 \\
31.2\end{array}$ & \begin{tabular}{r|r|r}
15.8 & 0.4 \\
14.1 & \\
20.2 &
\end{tabular} & $\begin{array}{c}13.2 \\
- \\
10.6 \\
25.2\end{array}$ & $\begin{array}{r}19.3 \\
\overline{-} \\
11.2 \\
34.8\end{array}$ & $\begin{array}{r}16.7 \\
- \\
6.2 \\
40.7\end{array}$ & $\begin{array}{r}7.2 \\
- \\
8.7 \\
55.1\end{array}$ & $\begin{array}{r}16.3 \\
- \\
8.0 \\
36.7\end{array}$ \\
\hline Total & 62.8 & 64.6 & 64.6 & 63.0 & 64.5 & 61.9 & 59.6 & 50.5 & 49.0 & 65.3 & 63.6 & 71.0 & 61.0 \\
\hline $\begin{array}{l}\text { Total } \\
\mu \mathrm{mole} / \mathrm{g}\end{array}$ & 37.12 & 67.04 & 88.72 & 2.54 & 250.06 & 8.57 & 16.29 & 0.552 & 0.151 & 0.348 & 0.275 & 0.069 & 0.349 \\
\hline Total mg/g & 6.50 & 11.75 & 15.68 & 0.45 & 43.08 & 1.50 & 2.84 & 0.095 & 0.026 & 0.060 & 0.048 & 0.012 & 0.061 \\
\hline $\begin{array}{l}\text { \% Sugar-C of } \\
\text { Total Org.-C }\end{array}$ & - & 5.8 & 9.0 & - & 6.6 & 1.6 & 1.5 & 0.59 & 0.30 & 0.45 & 0.26 & 0.10 & 0.36 \\
\hline $\begin{array}{l}\text { Glucose/ } \\
\text { Ribose }\end{array}$ & 14.1 & 15.9 & 16.6 & 34.5 & 35.6 & 25.5 & 18.2 & 6.2 & 6.3 & 20.2 & 18.7 & 19.0 & 18.3 \\
\hline Sugar/AA & 0.67 & 0.96 & 1.67 & - & 11.53 & - & - & 0.53 & 0.12 & 0.25 & 0.20 & 0.11 & 0.13 \\
\hline$\%$ Org. $-\mathrm{C}$ & N.D..$^{a}$ & 8.13 & 7.02 & N.D. ${ }^{a}$ & 26.0 & 3.71 & 7.40 & 0.65 & 0.35 & 0.54 & 0.72 & 0.48 & 0.67 \\
\hline
\end{tabular}

${ }^{\mathrm{a}} \mathrm{Hydrolyzed}$ in $2.0 \mathrm{~N} \mathrm{HCl}, 3 \mathrm{hr}, 100^{\circ} \mathrm{C}$; all other samples $72 \% \mathrm{H}_{2} \mathrm{SO}_{4} \rightarrow 1.86 \mathrm{~N}, 4 \mathrm{hr}, 100^{\circ} \mathrm{C}$.

See Table 3 for analyses in different acids.

cFructose not separated from xylose.

${ }^{\mathrm{d}}$ Not determined.

at the time of burial. Insights into this problem are attainable through an analysis of the metal associated fraction of the organic matter. Mopper (1973) and Degens and Mopper (1975, 1976) observed that the intensity of biological degradation, the degree of metal association of sugars and amino acid, and the oxidation potential at the sediment-water interface are interrelated. Thus by determining the degree of metal association one can speculate about the state of oxidation and hence biological activity at the time of deposition. Analyses are presently being conducted.

In Figure 4 an approximate inverse relationship appears to exist between the glucose-ribose ratio and the percent of $\mathrm{CaCO}_{3}$. A high ratio (terrigenous input) corresponds to a time of low $\mathrm{CaCO}_{3}$ deposition and vice versa. An exception is the $5 \times 10^{6}$ years sample (38154-1). The hydrocarbon profile for this sample (Figure 2) strongly indicates a terrigenous source. The discrepancy in the sugar data probably lies in the extraction; $2.0 \mathrm{~N} \mathrm{HCl}$ was employed for hydrolysis. Extraction with the $72 \% \mathrm{H}_{2} \mathrm{SO}_{4}$ method is expected to eliminate this problem.

Sapropel Section 379A-11-5 (26.0\% organic C, $0.0 \%$ $\mathrm{CaCO}_{3}, 0.06 \times 10^{6}$ years old) appears to have two distinct sources of input. The amino acid composition on a molar basis (Table 2) is very similar to that of the modern sapropel which is of planktonic origin. However, the amino acid carbon represents less than $0.5 \%$ of the organic matter in Section $379-11-5$ as opposed to $5 \%$ in modern sediment, as reflected in the $\mathrm{C} / \mathrm{N}$ ratios for these samples (Figure 4 ). These findings suggest a minor planktonic source. Similarly the hydrocarbon spectra for Section 379A-11-5 (Figure 1) primarily reflects a planktonic source but, as previously stated, the quantity of hydrocarbons extracted was much less than expected for the high organic content of the sediment. The hydrocarbons thus also appear to be related to this minor plankton source. The sugars, in contrast, are definitely related to a major terrigenous source as revealed by the high glucose-ribose ratio and the high percentage of sugar carbon of the total organic carbon (Figure 4). Thus, through a combination of various organic geochemical methods, one can gain valuable insights into the sources of sedimentary organic inputs.

\section{ACKNOWLEDGMENTS}

This work was supported by a grant from the Deutsche Forschungsgemeinschaft, DFG, De 74/7-9. We also thank Mr. F. Khoo for the carbonate determinations and Dr. H. Wehner for the organic carbon and nitrogen analyses. 
TABLE 4 - Continued

\begin{tabular}{|c|c|c|c|c|c|c|c|c|c|c|c|c|}
\hline \multirow[b]{2}{*}{$35-1$} & \multirow[b]{2}{*}{$37-6^{b}$} & \multicolumn{3}{|c|}{ Hole $380 \mathrm{~A}$ - Continued } & \multirow[b]{2}{*}{$62, \mathrm{CC}$} & \multirow[b]{2}{*}{$78, \mathrm{CC}$} & \multirow[b]{2}{*}{$23-3^{b}$} & \multirow[b]{2}{*}{$29-2$} & \multicolumn{2}{|c|}{ Site 381} & \multirow[b]{2}{*}{$48-4$} & \multirow[b]{2}{*}{$54-1$} \\
\hline & & $42, \mathrm{CC}$ & 45 (top) & $56-3$ & & & & & $29-6$ & 34 (top) & & \\
\hline $646^{\mathrm{a}}$ & $672^{\mathrm{a}}$ & $722^{\mathrm{a}}$ & $741^{\mathrm{a}}$ & 849 & $912^{\mathrm{a}}$ & 1064 & 220 & $258^{\mathrm{a}}$ & $265^{\mathrm{a}}$ & $304^{a}$ & 440 & $494^{\mathrm{a}}$ \\
\hline 1.9 & 2.0 & 2.3 & 2.4 & 2.6 & $\sim 3$ & $\sim 4$ & 1.8 & 2.2 & 2.3 & 2.4 & $\sim 3.1$ & 5 \\
\hline $\begin{array}{l}2.9 \\
\text { tr }\end{array}$ & $\begin{array}{l}9.4 \\
7.3\end{array}$ & $\begin{array}{l}1.1 \\
\text { tr }\end{array}$ & $\begin{array}{l}2.1 \\
\text { tr }\end{array}$ & $\begin{array}{r}14.1 \\
1.8\end{array}$ & $\begin{array}{l}\mathrm{tr} \\
4.9\end{array}$ & $\begin{array}{l}8.0 \\
4.0\end{array}$ & $\begin{array}{l}9.1 \\
0.8\end{array}$ & $\begin{array}{l}9.7 \\
2.8\end{array}$ & $\begin{array}{l}8.7 \\
4.8\end{array}$ & $\begin{array}{l}3.5 \\
\text { tr }\end{array}$ & $\begin{array}{c}3.1 \\
-\end{array}$ & $\begin{array}{l}2.3 \\
1.3\end{array}$ \\
\hline 2.9 & 16.7 & 1.1 & 2.1 & 15.9 & 4.9 & 12.0 & 9.9 & 12.5 & 13.5 & 3.5 & 3.1 & 3.6 \\
\hline 2.5 & 7.4 & 5.8 & 3.2 & 1.2 & tr & 3.5 & 0.4 & 3.9 & 2.5 & 1.6 & 2.5 & 4.2 \\
\hline tr & 7.4 & $\operatorname{tr}$ & $\mathrm{tr}$ & - & - & 1.3 & 0.9 & 0.9 & 0.4 & - & tr & 1.3 \\
\hline 33.8 & 10.5 & 45.4 & 27.5 & 6.7 & 1.7 & 13.7 & 6.0 & 16.8 & 11.1 & 15.4 & 6.3 & 48.3 \\
\hline 14.4 & 8.9 & 4.0 & 3.2 & 9.2 & 1.7 & 11.1 & 11.7 & 14.6 & 3.8 & 2.3 & 6.9 & 7.6 \\
\hline 50.7 & 34.2 & 55.1 & 33.9 & 17.1 & 3.4 & 29.6 & 19.0 & 36.2 & 17.8 & 19.3 & 15.7 & 61.4 \\
\hline tr & 6.9 & 8.5 & 18.5 & tr & 6.0 & 6.2 & 1.0 & 6.9 & 15.0 & 15.4 & 13.8 & 3.2 \\
\hline tr & 6.8 & - & - & $\mathrm{tr}$ & - & tr & - & - & - & - & tr & - \\
\hline- & 13.7 & 8.5 & 18.5 & - & 6.0 & 6.2 & 1.0 & 6.9 & 15.0 & 15.4 & 13.8 & 3.2 \\
\hline 11.0 & 11.0 & 10.9 & 10.6 & 8.6 & 9.8 & 6.6 & 24.2 & 15.4 & 14.9 & 15.7 & 6.9 & 10.2 \\
\hline$=0$ & $\overline{0}$ & tr & $\mathrm{tr}$ & - & - & $\overline{-}$ & - & $\mathrm{tr}$ & - & $\mathrm{tr}$ & $\overline{-}$ & tr \\
\hline 5.8 & 8.1 & 3.9 & 3.2 & 11.0 & - & 12.8 & 9.2 & 8.8 & 11.6 & 10.4 & 8.8 & 3.7 \\
\hline 29.7 & 16.3 & 20.4 & 31.7 & 47.2 & 75.6 & 32.7 & 36.6 & 20.1 & 27.9 & 35.7 & 52.5 & 17.6 \\
\hline 46.5 & 35.4 & 35.2 & 45.5 & 66.8 & 85.4 & 52.1 & 70.0 & 44.3 & 54.4 & 61.8 & 68.2 & 31.5 \\
\hline 0.556 & 0.648 & 0.241 & 0.189 & 0.163 & 0.035 & 0.226 & 0.781 & 0.651 & 0.568 & 0.273 & 0.160 & 0.16 \\
\hline v.092 & 0.115 & 0.039 & 0.032 & 0.029 & 0.006 & 0.039 & 0.14 & 0.11 & 0.10 & 0.048 & 0.028 & 0.02 \\
\hline- & 0.30 & 0.09 & 0.05 & 0.06 & 0.03 & 0.06 & 0.45 & 0.38 & 0.25 & 0.15 & 0.13 & 0.06 \\
\hline 11.8 & 2.2 & 3.6 & 10.0 & 38.5 & 13.0 & 9.3 & 95.3 & 5.0 & 11.3 & 24.5 & 21.0 & 4.1 \\
\hline- & 0.60 & 0.44 & 0.23 & 0.14 & 0.063 & 0.19 & - & 0.63 & 0.86 & 0.46 & - & 0.41 \\
\hline N.D. & 1.45 & 1.80 & 2.39 & 1.94 & 0.90 & 2.63 & 1.20 & 1.23 & 1.14 & 1.23 & 0.89 & 1.84 \\
\hline
\end{tabular}

\section{REFERENCES}

Albrecht, P. and Ourisson, G. 1971. Biogene substanzen in sedimenten und fossilien: Angew. Chem., v. 83, p. 221260.

Degens, E.T. and Mopper, K., 1975. Early diagenesis of organic matter in marine soils: Soil Sci., v. 119, p. 65-72. 1976. Factors controlling the distribution and early diagenesis of organic material in marine sediments: Chem. Oceanogr., v. 6, p. 59-113.

Degens, E.T. and Reuter, J.H., 1964. Analytical techniques in the field of organic geochemistry. In Colombo, U. and Hobson, G.D. (Eds.), Advances in organic geochemistry: (Pergamon Press), p. 377-402.
Mopper, K., 1973. Aspects of the biogeochemistry of carbohydrates in aquatic environments: Ph.D. Thesis, Mass. Inst. Tech., Woods Hole Oceanogr. Inst.

, in press. Sugars and uronic acids in sediment and water from the Black Sea and North Sea with emphasis on analytical techniques: Chem. Geol.

Mopper, K. and Degens, E.T., 1972. Tech. Rep. Woods Hole Oceanogr. Inst., v. 72-68, p. 1-117.

Mopper, K. and Gindler, E.M., 1973. A new noncorrosive dye reagent for automatic sugar chromatography: Anal. Biochem., v. 56, p. 440.

Nissenbaum, A., Baedecker, M.J., and Kaplan, I.R., 1972. In Gaertner, H.R.v. and Wehner, H., (Eds.), New York (Pergamon Press), p. 427-500. 